Editorial

\title{
Long-time gastric protection
}

\section{Introduction}

"Gastricprotection" has popularized the use of proton pump inhibitors (PPI) and often are used for any reason without medical control, like after a heavy alcohol intake, in mild heart burn or dyspepsia. The drugs used are Omeprazol, Lanzoprazol, Esemeprazol etc. These drugs decline the acid secretion of the stomach as the main effect. Many people use them at their convenience. Some manufacters has recommended "manteinance dose" for months and years, this is not convenient. Their sales in USA are \$10.billion in 2001 and \$ 13.8 billions in 2008, is the drug most sold in the world. ${ }^{1}$

They are used in routine hospitalization and $65-70 \%$ did not need it and are used as unnecessary mantainance dose too. ${ }^{2}$ It has been reported that bloking the gastric secretion leads to pneumonia and bronchopneumonia because bacteria are not destroyed. ${ }^{3}$ Prolonged use of PPIs affect the absorption of vitamin B12. Its use by more tan 6 months increase Clostridium Difficile disease of 5 to $23 \%{ }^{4,5}$ There have been case reports implicating these drugs in acute intestitial nephritis and progression to acute renal failure. ${ }^{6}$

\section{Conclusion}

The PPIs should de used for a maximun of 6-8 weeks as illness required, a large number of patients are taking PPIs for no clear reason. PPIs should be stopped to determinate if symptomatic treatment is needed.

\section{Acknowledgments}

None.

\section{Conflicts of interset}

Author declare that there is no conflict of interest.

\section{Funding}

None.

\section{References}

1. Forgacs I, Loganayagam A. Overprescribing proton pump inhibitors. BMJ. 2008;336(7634):2-3.
Volume 4 Issue 3 - 2016

\section{Nelson Carrillo \\ Department of Gastroenterology, University of Venezuela, Venezuela}

Correspondence: Nelson Carrillo, Department of Gastroenterology, University of Venezuela, Libertador Avenue, Angostura Building, 7 Floor, Office 7B, Caracas, Venezuela, Tel 58212-7632202, Fax 58-212-9917903, Email ncp@yahoo.com

Received: January 13, 2016 | Published: February 22, 2016
2. Nardino RJ, Vender RJ, Herbert PN. Over use of acid supressive therapy in hospitalized patients. Am J Gast. 2000;95(11):3118-3122.

3. Laheij RJ, Sturkenboom MC, Hassing RJ, et al. Risk of communityadquired pneumonia and use of gastric supressive drugs. JAMA. 2004;292(16):1955-1960.

4. Savarino V, Di Mario F, Scarpignato C. Proton pump inhibitors in GORD-An overview of the pharmacology and safety. Phamacol Res. 2009;59(3):135-153.

5. Dalton BR, Lye-Maccannell T, Henderson EA, et al. Proton pump inhibitors increase significantly the risk of Clostridium difficile infection in a low-endemicity, non-outbreak hospital setting. Phanacol Ther. 2009;29(6):626-634.

6. Geevasinga N, Coleman PL, Webster AC, et al. Proton pump inhibitors and acute interstitial nephritis. Clin Gastroenterol Hepatol. 2006;46(5):597-604. 